\title{
Establishment of Adequate Nutrient Intake Criteria to Achieve Target Weight Loss in Patients Undergoing Bariatric Surgery
}

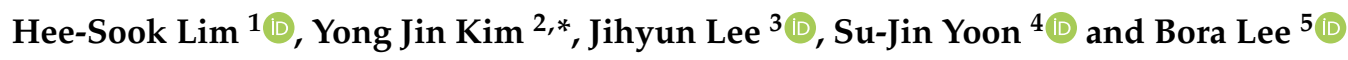 \\ Department of Food and Nutrition, Yeonsung University, Anyang 14011, Korea; limhs@yeonsung.ac.kr \\ Department of General Surgery, H Plus Yang Ji Hospital, Seoul 08779, Korea \\ Department of Nutrition, H Plus Yang Ji Hospital, Seoul 08779, Korea; dlikej@naver.com \\ Department of Nutrition, Soonchunhyang University Seoul Hospital, Seoul 04401, Korea; exski@schmc.ac.kr \\ Department of Statistics, Chung-Ang University, Seoul 06911, Korea; mintbora0125@gmail.com \\ * Correspondence: yjgs1997@gmail.com; Tel.: +82-2-070-4665-9517
}

Received: 22 April 2020; Accepted: 12 June 2020; Published: 14 June 2020

check for updates

\begin{abstract}
Although bariatric surgery is the best treatment modality for morbidly obese patients, a $10-30 \%$ rate of weight recidivism has been reported in various specialized centers. We examined changes in energy and macronutrients after bariatric surgery and performed analysis to establish appropriate nutritional guidelines for reaching the target percentage of weight loss after surgery. A total of 189 subjects who underwent bariatric surgery were classified into success and failure groups depending on whether or not they reached $50 \%$ loss of excess weight at 12 months after bariatric surgery. Physical examinations and dietary surveys were completed before and 1, 6, and 12 months after surgery. Using receiver operating characteristic (ROC) analysis, the optimal cutoff points for nutrient intakes for determining success after bariatric surgery were computed based on maximal Youden's index. At 6 and 12 months after surgery, the success group had significantly lower carbohydrate and fat intakes than the failure group. The cutoff calorie intake for success in weight loss was $<835.0,<1132.5$, and $<1523.0 \mathrm{kcal} /$ day at 1,6 , and 12 months post operation, respectively. With regard to protein, the cutoff intakes were $>44.5,>41.5$, and $>86.5 \mathrm{~g} /$ day at 1,6 , and 12 months post operation, respectively. At 12 months, the cutoff ratio for energy obtained from carbohydrates, protein, and fat was $<49.0,>24.5$, and $<28.0 \%$, respectively. Our findings confirm that the level of diet control and nutrition restriction affect the achievement of target weight loss, emphasizing that long-term weight loss is related to compliance with nutrient recommendations.
\end{abstract}

Keywords: bariatric surgery; nutrition; weight loss; caloric restriction; diet

\section{Introduction}

Bariatric surgery is currently the effective treatment for long-term weight loss and the improvement of obesity-related comorbidities in morbidly obese patients [1]. The most significant advantage of the surgical procedure is a large weight loss effect achieved by reduced food intake and malabsorption, and this weight loss can be maintained in the long term [2]. However, side effects can cause various changes in the intestine after surgery and malnutrition due to the reduced dietary intake [3].

Patients are encouraged to receive nutritional management before and after bariatric surgery as well as nutritional education from experts, including blood tests and nutritional assessments [4]. In general, bariatric surgery is considered successful if more than $50 \%$ of the excess weight is lost over 2 years [5]. A poor-quality diet, lack of physical activity, and lack of continuous nutritional management are the main reasons for failure, along with excessive energy consumption and overeating 
after surgery [6,7]. Therefore, assessment of patients' eating patterns and individualized nutritional management are critical for successful long-term weight loss.

Surgical procedures are effective for successful weight loss, but nutrient intake after surgery also plays a key role in achieving the long-term goals $[2,4]$. The recommended percentage of energy intake from carbohydrates after bariatric surgery is $35-48 \%$, with an intake of at least $60-80 \mathrm{~g}$ protein/day [8-10]. There have been a number of studies on calorie intake and nutrient deficiency, but the results in relation to weight loss vary $[3,8]$. In addition, the specific criteria guidelines for proper nutrient intake according to the surgical overtime point are insufficient. In Korea, proper standards for carbohydrate-based meals need to be set, as there is only a broad guideline of 1000-1400 kcal/day after surgery [11].

This study was performed to explore the relationship between energy intake after bariatric surgery and weight loss, and to establish appropriate nutritional guidelines to reach the target percentage of weight loss after surgery.

\section{Materials and Methods}

\subsection{Subjects}

This retrospective observational study used data from a single center. The eligibility criteria for bariatric surgery were an age of $20-65$ years with a BMI $\geq 35 \mathrm{~kg} / \mathrm{m}^{2}$ or BMI $\geq 30 \mathrm{~kg} / \mathrm{m}^{2}$ and a comorbidity related to obesity [12]. All eligible subjects underwent bariatric surgery between April 2013 and January 2018, and all the surveys and management were conducted at each visit. Subjects with absence of data on diet or weight loss after surgery and those who underwent hospitalization or reoperation due to complications after surgery, were excluded. A total of 189 patients were included in the analysis. The study protocol was approved by the Institutional Review Board of Soon Chun Hyang University Seoul Hospital (IRB number: SCH IRB 2019-02-006; approval date: 7 March 2019). Written informed consent was obtained from all patients. All subjects voluntarily agreed to participate in the study after receiving a detailed description of the procedures and goals. The study protocol conformed to the ethical guidelines of the World Medical Association Declaration of Helsinki.

\subsection{General Characteristics and Anthropometric Measurements}

The baseline demographics of the enrolled subjects-including age, sex, body mass index (BMI), and lifestyle habits (alcohol drinking, smoking, exercise, and experience with diet control) - at the time of the operation and anthropometric data at all follow-up time points were collected from the metabolic and obesity surgery database and hospital medical records. Measurements of body composition were performed at each follow-up time with a bioelectrical impedance analyzer (Biospace In-body 720, Seoul, Korea). Using the checked height and weight, we calculated the body mass index $\left(\mathrm{BMI}, \mathrm{kg} / \mathrm{m}^{2}\right)$. Fat free mass (FFM) was calculated by subtracting fat mass from body weight (FFM = Body weight - (Body weight $\times$ Fat $\%)$ ). \%Excess weight loss (\%EWL) was calculated using the formula (weight loss/baseline excess weight) $\times 100$, where weight loss = preoperative weight-initial weight; baseline excess weight $=$ initial weight-ideal weight $(X)$, and $X=23 \times$ height $(m)^{2} . X$ was calculated using an ideal BMI, as the ideal BMI cutoff point has been demonstrated to be $23 \mathrm{~kg} / \mathrm{m}^{2}$ [13]. All subjects were classified into success and failure groups based on \%EWL 50\% at 12 months after bariatric surgery.

\subsection{Dietary Intake Analysis}

Our institute has a protocol for nutritional management procedures about for nutritional assessments, nutritional education, and counseling-preoperatively and at 1, 3, 6, and 12 months post operation via interviews between the individual patient and a clinical dietitian. The clinical dietitian calculated the average daily nutrient intake based on 3-day food records for all foods and drinks. The consumed food was analyzed using Computer Aided Nutritional Analysis Program for Professionals 4.0 (CAN-Pro 4.0, The Korean Nutrition Society, Korea) that analyzes the intake of individual nutrients. 


\subsection{Follow-Up}

Subject's data were obtained preoperatively and at 1,6, and 12 months post operation. Changes in anthropometric status and nutrient intake were analyzed at each visit.

\subsection{Statistical Analyses}

Power calculation was conducted to determine the sample size required to detect the clinical effect via PASS (ver 12. NCSS, LLC. Kaysville, Utah, USA; www.ncss.com). It was figured out that 127 subjects from the success group and 62 from the failure group provided 93 to $100 \%$ power to detect a difference in the range of 0.0310 to 0.1620 between the areas under the ROC curve (AUCs) of the calorie, carbohydrate, and fat intakes at 12 months post operation and the null hypothesis; and an AUC of 0.75, which has clinical meaning as a diagnostic tool; while the two-sided z-test was set at a significance level of 0.05 . The demographic characteristics and clinical factors of the subjects are presented as means \pm standard deviation for continuous variables and as frequencies with percentages for categorical variables. Success and failure groups were compared for the change in amount of body weight, the proportion of the categorized \%EWL, and the nutrition intakes at each follow-up time. Wilcoxon's rank sum test was used for comparing the continuous variables and the $\chi^{2}$ test or Fisher's exact test were used for comparing the categorical variables as appropriate. The associations between \%EWL and macronutrient intake levels at 12 months post operation were evaluated by Pearson's method. Logistic regression analysis was performed for factors affecting \%EWL success. Using receiver operating characteristic (ROC) analysis, the optimal cutoff points of nutrient intakes for determining success after bariatric surgery were computed based on maximal Youden's index. The sensitivity, specificity, accuracy, positive likelihood ratio (LR+), and negative likelihood ratio (LR-) of the successful weight loss are presented with 95\% confidence intervals (CIs), which were calculated by exact binomial distribution for sensitivity, specificity, and accuracy and a formula provided by Simel et al. [14] for positive and negative likelihood ratios. All analyses were carried out using R (version 3.6.3; The R Foundation for Statistical Computing, Vienna, Austria), and a two-sided $p$-value of less than 0.05 was considered to indicate statistical significance.

\section{Results}

\subsection{Clinical Characteristics and Weight Loss}

The general characteristics and weight loss results of the 189 subjects are shown in Tables 1 and 2, respectively. The average age was 34.6 years, and $71.4 \%$ of them were female. The surgical method was laparoscopic Roux-en-Y gastric bypass (LRYGB) in $77.2 \%$ and sleeve gastrectomy (SG) in $22.8 \%$ of subjects. The main comorbidities included diabetes, dyslipidemia, and hypertension. The rates of lifestyle habits before surgery were as follows: alcohol drinking, $34.9 \%$; smoking, $46 \%$; exercise, $14.8 \%$; and experience with diet control, $46.0 \%$. The average BMI was $38.9 \pm 5.9 \mathrm{~kg} / \mathrm{m}^{2}$, and the amount of excess weight was $44.2 \pm 16.6 \mathrm{~kg}$. The average \%EWL at 1,3,6, and 12 months post operation were $24.69 \%, 41.66 \%, 46.42 \%$, and $53.05 \%$, respectively. Whereas the success group had an average $\% E W L$ of $52.76 \%$ at 6 months, the \%EWL was delayed by 6 months in the failure group, and the \%EWL was $37.46 \%$ at 12 months. The average $\%$ EWL according to the operative method and comorbidity showed no significant differences. 
Table 1. Baseline characteristics in all patients.

\begin{tabular}{|c|c|}
\hline Variable & Total $(n=189)$ \\
\hline Age (years) & $34.6 \pm 10.7$ \\
\hline \multicolumn{2}{|l|}{ Sex } \\
\hline Male & $54(28.6 \%)$ \\
\hline Female & $135(71.4 \%)$ \\
\hline \multicolumn{2}{|l|}{ Operative method } \\
\hline LRYGB & $146(77.2 \%)$ \\
\hline SG & $43(22.8 \%)$ \\
\hline \multicolumn{2}{|l|}{ Comorbidity } \\
\hline Yes & $43(22.8 \%)$ \\
\hline Diabetes & $18(9.5 \%)$ \\
\hline Hypertension & $10(5.3 \%)$ \\
\hline Hyperlipidemia & $11(5.8 \%)$ \\
\hline Joint problem & $6(3.2 \%)$ \\
\hline Depression & $4(2.1 \%)$ \\
\hline Apnea & $7(3.7 \%)$ \\
\hline \multicolumn{2}{|l|}{ Number of comorbidities } \\
\hline One & $26(60.4 \%)$ \\
\hline Two & $11(25.6 \%)$ \\
\hline Three or more & $6(14.0 \%)$ \\
\hline \multicolumn{2}{|l|}{ Lifestyle habit } \\
\hline Alcohol drinking & $66(34.9 \%)$ \\
\hline Smoking & $36(19.0 \%)$ \\
\hline Exercise & $28(14.8 \%)$ \\
\hline Experience of diet control & $86(46.0 \%)$ \\
\hline Weight (kg) & $108.0 \pm 19.8$ \\
\hline BMI $\left(\mathrm{kg} / \mathrm{m}^{2}\right)$ & $38.9 \pm 5.9$ \\
\hline Excess weight $(\mathrm{kg})$ & $44.2 \pm 16.6$ \\
\hline Fat Mass (kg) & $55.7 \pm 11.3$ \\
\hline Fat Free Mass (kg) & $51.6 \pm 13.9$ \\
\hline
\end{tabular}

LRYGB, Roux-en-Y gastric bypass; SG, sleeve gastrectomy. Data are reported as mean \pm SD for continuous variables and $n(\%)$ for categorical variables. 
Table 2. Changes in percentage of excess weight loss (\%EWL) between two groups.

\begin{tabular}{|c|c|c|c|c|c|c|c|c|c|c|}
\hline \multirow[b]{2}{*}{ Variable } & \multirow[b]{2}{*}{$\begin{array}{c}\text { Total } \\
(n=189)\end{array}$} & \multicolumn{3}{|c|}{ Achievement of Weight Loss } & \multicolumn{3}{|c|}{ Operative Method } & \multicolumn{3}{|c|}{ Comorbidity } \\
\hline & & $\begin{array}{c}\text { Success } \\
(n=127)\end{array}$ & $\begin{array}{l}\text { Failure } \\
(n=62)\end{array}$ & $p$-Value & $\begin{array}{c}\text { LRYGB } \\
(n=146)\end{array}$ & $\begin{array}{c}\text { SG } \\
(n=43)\end{array}$ & $p$-Value & $\begin{array}{c}\text { Yes } \\
(n=43)\end{array}$ & $\begin{array}{c}\text { No } \\
(n=146)\end{array}$ & $p$-Value \\
\hline Postop 1 month & $24.69 \pm 9.23$ & $25.85 \pm 10.00$ & $22.50 \pm 6.52$ & 0.005 & $24.52 \pm 9.66$ & $25.24 \pm 7.64$ & 0.615 & $24.59 \pm 7.82$ & $25.25 \pm 13.39$ & 0.695 \\
\hline Postop 3 months & $41.66 \pm 11.57$ & $45.38 \pm 10.87$ & $34.03 \pm 8.96$ & $<0.001$ & $42.18 \pm 12.91$ & $41.50 \pm 11.19$ & 0.736 & $45.35 \pm 16.06$ & $48.71 \pm 17.57$ & 0.258 \\
\hline Postop 6 months & $46.42 \pm 17.27$ & $52.76 \pm 17.12$ & $33.48 \pm 7.78$ & $<0.001$ & $50.05 \pm 18.66$ & $46.67 \pm 16.75$ & 0.289 & $41.98 \pm 10.87$ & $42.24 \pm 13.58$ & 0.900 \\
\hline Postop 12 months & $53.05 \pm 15.90$ & $61.71 \pm 7.90$ & $37.46 \pm 10.21$ & $<0.001$ & $54.40 \pm 16.38$ & $53.57 \pm 13.75$ & 0.762 & $53.15 \pm 14.80$ & $54.81 \pm 13.81$ & 0.511 \\
\hline
\end{tabular}

LRYGB, Roux-en-Y gastric bypass; SG, sleeve gastrectomy. Data are reported as mean \pm SD and $p$-values were calculated with Wilcoxon's rank-sum test.

\subsection{Changes in Nutrient Intake over Time}

The changes in nutritional intake before and after surgery are shown in Table 3. There were no significant differences in the intake of macronutrients or calories before surgery between the two groups. At 1 month post operation, the calorie intake was about 760 kcal in two groups, and the protein intake was $58.02 \mathrm{~g}$ in the success group and $50.55 \mathrm{~g}$ in the failure group. At 6 months, the calorie intake was $999.82 \mathrm{kcal}$ in the success group ( $p=0.004)$, and the carbohydrate $(p<0.001)$ and fat intakes $(p=0.022)$ were significantly lower in the success group. At 12 months, the calorie intake was 1336.75 kcal in the success group and $1646.21 \mathrm{kcal}$ in the failure group $(p<0.001)$. Comparing the energy ratios of macronutrients, the carbohydrate ratio was significantly lower at 1 month $(p=0.031)$ and 12 months $(p=0.004)$ in the success group, the protein ratio was significantly higher at 6 months $(p<0.021)$ and 12 months $(p=0.010)$ in the success group, and the fat ratio was significantly lower at 12 months $(p=0.040)$ in the success group.

Table 3. Comparison of nutrition intakes between two groups.

\begin{tabular}{|c|c|c|c|c|c|c|c|c|c|c|c|c|}
\hline \multirow[b]{2}{*}{ Variable } & \multicolumn{3}{|c|}{ Calorie (kcal) } & \multicolumn{3}{|c|}{ Carbohydrate (g) } & \multicolumn{3}{|c|}{ Protein $(g)$} & \multicolumn{3}{|c|}{ Fat (g) } \\
\hline & $\begin{array}{l}\text { Success } \\
(n=127)\end{array}$ & $\begin{array}{l}\text { Failure } \\
(n=62)\end{array}$ & $p$-Value & $\begin{array}{l}\text { Success } \\
(n=127)\end{array}$ & $\begin{array}{l}\text { Failure } \\
(n=62)\end{array}$ & $p$-Value & $\begin{array}{l}\text { Success } \\
(n=127)\end{array}$ & $\begin{array}{l}\text { Failure } \\
(n=62)\end{array}$ & $p$-Value & $\begin{array}{l}\text { Success } \\
(n=127)\end{array}$ & $\begin{array}{l}\text { Failure } \\
(n=62)\end{array}$ & $p$-Value \\
\hline Preop & $2282.97 \pm 626.93$ & $2234.31 \pm 609.10$ & 0.610 & $\begin{array}{c}293.31 \pm 90.00 \\
(53.5 \%)\end{array}$ & $\begin{array}{c}311.18 \pm 113.16 \\
(56.4 \%)\end{array}$ & 0.280 & $\begin{array}{c}92.06 \pm 32.42 \\
(16.8 \%)\end{array}$ & $\begin{array}{c}84.02 \pm 28.75 \\
(15.1 \%)\end{array}$ & 0.086 & $\begin{array}{c}74.24 \pm 32.67 \\
(29.9 \%)\end{array}$ & $\begin{array}{c}70.77 \pm 31.61 \\
(28.5 \%)\end{array}$ & 0.485 \\
\hline Postop 1 month & $769.33 \pm 217.88$ & $765.73 \pm 178.30$ & 0.904 & $\begin{array}{c}70.48 \pm 34.82 \\
(36.7 \%)\end{array}$ & $\begin{array}{c}70.56 \pm 35.47 \\
(39.6 \%)^{\mathrm{a}}\end{array}$ & 0.987 & $\begin{array}{c}58.02 \pm 21.95 \\
\quad(30.1 \%)\end{array}$ & $\begin{array}{c}50.55 \pm 23.74 \\
(28.9 \%)\end{array}$ & 0.040 & $\begin{array}{c}30.04 \pm 14.53 \\
(33.2 \%)\end{array}$ & $\begin{array}{c}27.59 \pm 14.25 \\
(31.5 \%)\end{array}$ & 0.272 \\
\hline Postop 6 months & $999.82 \pm 259.30$ & $1120.81 \pm 272.43$ & 0.004 & $\begin{array}{c}97.58 \pm 44.1 \\
(40.6 \%)\end{array}$ & $\begin{array}{c}133.98 \pm 54.96 \\
(46.4 \%)\end{array}$ & $<0.001$ & $\begin{array}{c}57.87 \pm 20.91 \\
\quad(25.4 \%)\end{array}$ & $\begin{array}{c}53.79 \pm 18.06 \\
(20.2 \%)^{\mathrm{b}}\end{array}$ & 0.169 & $\begin{array}{c}34.71 \pm 11.53 \\
(34.0 \%)\end{array}$ & $\begin{array}{c}38.98 \pm 12.10 \\
(33.4 \%)\end{array}$ & 0.022 \\
\hline Postop 12 months & $1336.75 \pm 229.03$ & $1646.21 \pm 315.55$ & $<0.001$ & $\begin{array}{c}139.13 \pm 49.04 \\
(48.4 \%)\end{array}$ & $\begin{array}{c}198.60 \pm 81.10 \\
(53.1 \%)^{\mathrm{A}}\end{array}$ & $<0.001$ & $\begin{array}{c}79.19 \pm 24.09 \\
(28.0 \%)\end{array}$ & $\begin{array}{c}70.43 \pm 25.04 \\
(20.4 \%)^{\mathrm{B}}\end{array}$ & 0.023 & $\begin{array}{c}47.87 \pm 12.32 \\
(23.6 \%)\end{array}$ & $\begin{array}{c}59.42 \pm 17.53 \\
(26.5 \%) \mathrm{C}\end{array}$ & $<0.001$ \\
\hline
\end{tabular}

Data are reported as mean \pm SD. P-values were computed by Wilcoxon's rank-sum test. Numbers of patients were 127 for success and 62 for failure. Data in parentheses report the average energy ratio for each macronutrient intake. ( ${ }^{\mathrm{a}} p<0.05$ vs. carbohydrate in postop 1 month, ${ }^{\mathrm{A}} p<0.01$ vs. carbohydrate in postop 12 months, ${ }^{\mathrm{b}} p<0.05$ vs. protein in postop 6 months, ${ }^{\mathrm{B}} p<0.05$ vs. protein in postop 12 months, ${ }^{\mathrm{C}} p<0.05 \mathrm{vs}$. fat in postop 12 months). 


\subsection{Correlation between $\%$ EWL and Nutrient Intake}

The correlations between \%EWL and nutrient intake at 12 months post operation are shown in Figure 1 . The $\%$ EWL in the success group was inversely related to calorie $(r=-0.418, p<0.0001)$ and fat intakes $(r=-0.273, p=0.0019)$. In the failure group, the $\%$ EWL showed inverse relationships with carbohydrate $(r=-0.3, p=0.018)$ and fat intakes $(r=-0.266, p=0.0365)$, while it showed a positive correlation with protein intake $(r=0.301, p=0.0175)$.

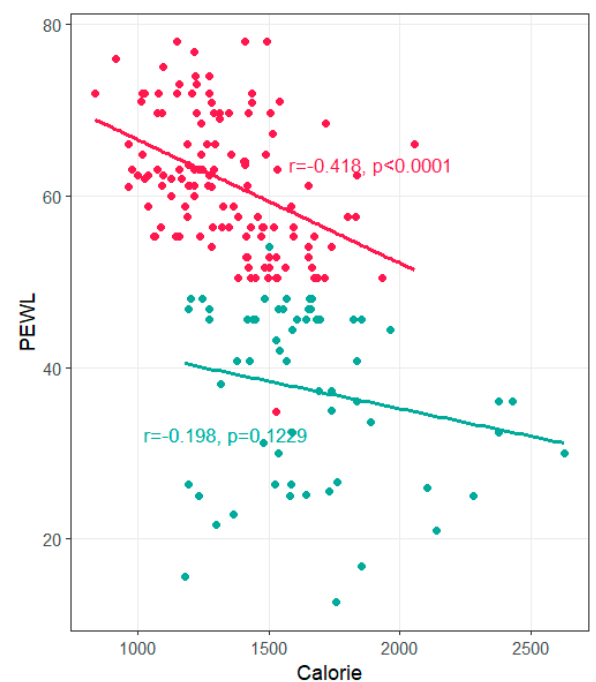

(a)

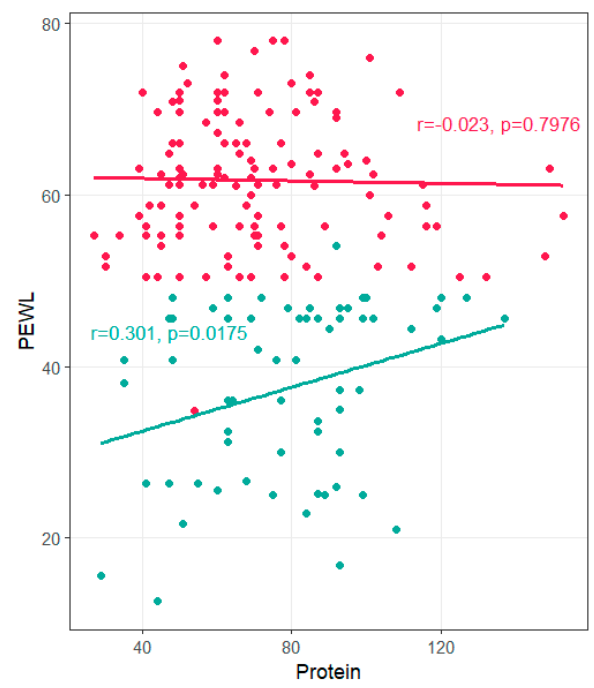

(c)

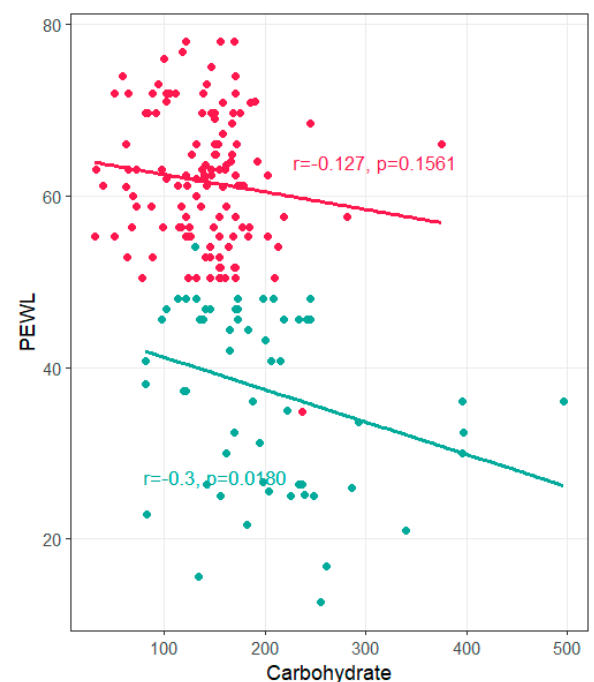

(b)
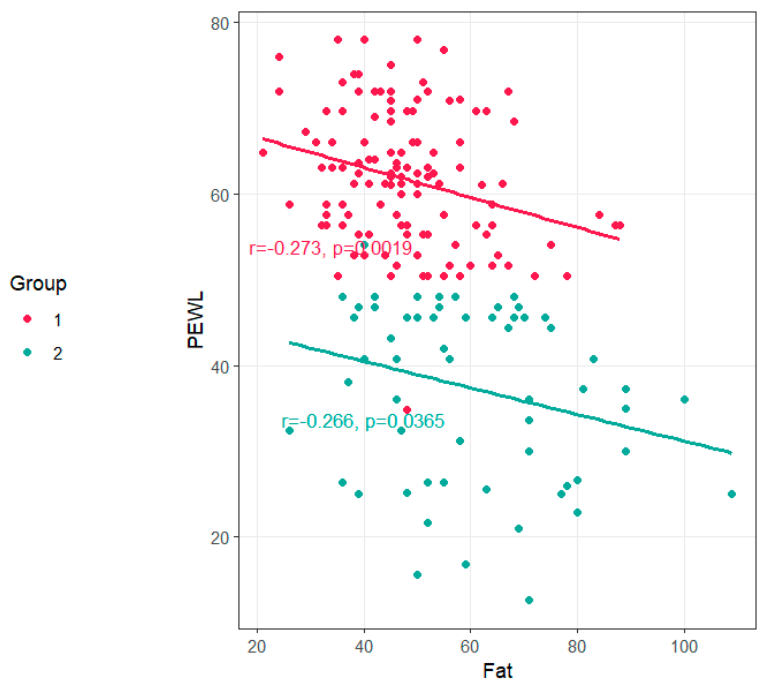

(d)

Figure 1. Scatterplot representing the association between $\% \mathrm{EWL}$ and macronutrient composition at postop 12 months. (a) correlation between \%EWL and calorie, (b) correlation between \%EWL and carbohydrate, (c) correlation between \%EWL and fat, (d) correlation between \%EWL and fat. Group 1; Success, Group 2; Failure. $P$-value was computed by pearson correlation test.

\subsection{Factors Affecting the \%EWL in Subjects}

The logistic regression analysis results for factors affecting \%EWL at 12 months post operation are shown in Table 4. In the univariable logistic regression, significant effects were confirmed for age, calories at 6 and 12 months, carbohydrates at 6 and 12 months, protein at 1 and 12 months, fat at 6 and 12 months, and all the proportions of calories at 12 months versus the three components. To avoid the multicollinearity in the regression analysis, the final model was created including age and the calorie 
proportion versus the three components. It shows an insignificant effect for the proportion of calories at 12 months versus protein (OR, 0.99; 95\% CI, 0.97\% to 1.00\%). Excluding this factor, the final model has the factors affecting \%EWL at 12 months as follows: lower age (OR, 0.96; 95\% CI, 0.93\% to 0.99\%), lower proportion of calories as carbohydrates (OR, $0.99 ; 95 \% \mathrm{CI}, 0.98 \%$ to $0.99 \%$ ), and proportion of calories as fat (OR $0.96 ; 95 \%$ CI, $0.93 \%$ to $0.98 \%$ ).

Table 4. Logistic regression analysis for the success in patients.

\begin{tabular}{|c|c|c|c|c|c|c|}
\hline \multirow{2}{*}{ Variable } & \multicolumn{2}{|c|}{ Univariable } & \multicolumn{2}{|c|}{ Multiple 1} & \multicolumn{2}{|c|}{ Multiple 2} \\
\hline & OR $(95 \%$ CI $)$ & $p$-Value & OR $(95 \%$ CI $)$ & $p$-Value & OR $(95 \% \mathrm{CI})$ & $p$-Value \\
\hline Age (year) & $0.96(0.93-0.99)$ & 0.009 & $0.97(0.94-0.99)$ & 0.046 & $0.96(0.93-0.99)$ & 0.027 \\
\hline Female & $1.83(0.94-3.52)$ & 0.072 & & & & \\
\hline LRYGB & $0.74(0.34-1.54)$ & 0.437 & & & & \\
\hline No. of comorbidities & $0.85(0.65-1.13)$ & 0.249 & & & & \\
\hline $\begin{array}{l}\text { Calorie }(100 \mathrm{kcal}) \\
\text { at } 1 \text { month } \\
\text { at } 6 \text { months } \\
\text { at } 12 \text { months }\end{array}$ & $\begin{array}{l}1.05(0.91-1.22) \\
0.78(0.68-0.88) \\
0.37(0.27-0.48)\end{array}$ & $\begin{array}{l}0.515 \\
<0.001 \\
<0.001\end{array}$ & & & & \\
\hline $\begin{array}{l}\text { Carbohydrates }(10 \mathrm{~g}) \\
\text { at } 1 \text { month } \\
\text { at } 6 \text { months } \\
\text { at } 12 \text { months }\end{array}$ & $\begin{array}{c}0.98(0.9-1.07) \\
0.85(0.78-0.91) \\
0.63(0.54-0.72)\end{array}$ & $\begin{array}{c}0.607 \\
<0.001 \\
<0.001\end{array}$ & & & & \\
\hline $\begin{array}{l}\text { Protein }(10 \mathrm{~g}) \\
\text { at } 1 \text { month } \\
\text { at } 6 \text { months } \\
\text { at } 12 \text { months }\end{array}$ & $\begin{array}{l}1.17(1.01-1.36) \\
0.99(0.85-1.15) \\
0.85(0.74-0.96)\end{array}$ & $\begin{array}{l}0.038 \\
0.853 \\
0.008\end{array}$ & & & & \\
\hline $\begin{array}{l}\text { Fat }(10 \mathrm{~g}) \\
\text { at } 1 \text { month } \\
\text { at } 6 \text { months } \\
\text { at } 12 \text { months }\end{array}$ & $\begin{array}{c}1.11(0.9-1.39) \\
0.55(0.41-0.72) \\
0.46(0.35-0.6)\end{array}$ & $\begin{array}{l}0.323 \\
<0.001 \\
<0.001\end{array}$ & & & & \\
\hline $\begin{array}{c}\text { Proportion of calories at } 12 \text { months } \\
\text { Carbohydrate }(\%) \\
\text { Protein }(\%) \\
\text { Fat }(\%)\end{array}$ & $\begin{array}{l}0.98(0.98-0.99) \\
0.99(0.97-1.00) \\
0.95(0.93-0.97)\end{array}$ & $\begin{array}{l}<0.001 \\
0.026 \\
<0.001\end{array}$ & $\begin{array}{l}0.98(0.98-0.99) \\
0.99(0.97-1.00) \\
0.96(0.93-0.99)\end{array}$ & $\begin{array}{l}<0.001 \\
0.171 \\
0.002\end{array}$ & $\begin{array}{l}0.99(0.98-0.99) \\
0.96(0.93-0.98)\end{array}$ & $\begin{array}{l}<0.001 \\
<0.001\end{array}$ \\
\hline
\end{tabular}

OR, odds ratio; CI, confidence interval.

\subsection{Optimal Nutrient Intakes for Determining Success after Bariatric Surgery}

The optimal cutoff point for nutrient intakes for determining success after bariatric surgery at each postoperative time point are shown in Table 5. The cutoff calorie intakes were $<835.0,<1132.5$, and $<1523.0 \mathrm{kcal} /$ day at 1,6 , and 12 months post operation, respectively. With regard to protein, the cutoff intakes were $>44.5,>41.5$, and $>86.5 \mathrm{~g} /$ day at 1,6 , and 12 months post operation, respectively. At 12 months, the cutoff percentages for calories obtained from carbohydrates, protein, and fat were $<49.0 \%,>24.5 \%$, and $<28.0 \%$, respectively. 
Table 5. Prognostic performance for the success in patients.

\begin{tabular}{|c|c|c|c|c|c|c|c|}
\hline \multirow{2}{*}{ Variable } & \multirow{2}{*}{ AUC (95\% CI) } & \multirow{2}{*}{ Optimal Cutoff * } & \multicolumn{5}{|c|}{ Estimates $(95 \% \mathrm{CI})$} \\
\hline & & & Sensitivity & Specificity & Accuracy & LR (+) & LR (-) \\
\hline \multicolumn{8}{|l|}{ Calories (kcal) } \\
\hline at 1 month & $0.529(0.442-0.615)$ & $<835.0$ & $0.57(0.48-0.65)$ & $0.32(0.21-0.45)$ & $0.49(0.41-0.56)$ & $0.84(0.67-1.05)$ & $1.34(0.89-2.03)$ \\
\hline at 6 months & $0.673(0.593-0.754)$ & $<1132.5$ & $0.75(0.66-0.82)$ & $0.55(0.42-0.68)$ & $0.68(0.61-0.75)$ & $1.66(1.24-2.22)$ & $0.46(0.32-0.67)$ \\
\hline at 12 months & $0.912(0.872-0.953)$ & $<1523.0$ & $0.87(0.79-0.92)$ & $0.82(0.7-0.91)$ & $0.85(0.79-0.90)$ & $4.88(2.84-8.38)$ & $0.16(0.10-0.26)$ \\
\hline \multicolumn{8}{|l|}{ Carbohydrate (g) } \\
\hline at 1 month & $0.513(0.424-0.602)$ & $<115.5$ & $0.91(0.85-0.96)$ & $0.15(0.07-0.26)$ & $0.66(0.59-0.73)$ & $1.07(0.95-1.20)$ & $0.60(0.26-1.36)$ \\
\hline at 6 months & $0.703(0.624-0.781)$ & $<103.0$ & $0.58(0.49-0.67)$ & $0.79(0.67-0.88)$ & $0.65(0.58-0.72)$ & $2.78(1.68-4.61)$ & $0.53(0.41-0.67)$ \\
\hline at 12 months & $0.878(0.819-0.937)$ & $<172.5$ & $0.93(0.87-0.97)$ & $0.76(0.63-0.86)$ & $0.87(0.82-0.92)$ & $3.84(2.47-5.98)$ & $0.09(0.05-0.18)$ \\
\hline \multicolumn{7}{|l|}{ Protein $(\mathrm{g})$} & $0.47(0.32-0.70)$ \\
\hline at 6 months & $0.524(0.440-0.609)$ & $>41.5$ & $0.86(0.79-0.91)$ & $0.02(0.00-0.09)$ & $0.58(0.51-0.65)$ & $0.87(0.81-0.94)$ & $8.79(1.02-64.33)$ \\
\hline at 12 months & $0.618(0.531-0.705)$ & $>86.5$ & $0.21(0.15-0.29)$ & $0.55(0.42-0.68)$ & $0.32(0.26-0.39)$ & $0.47(0.31-0.73)$ & $1.44(1.13-1.83)$ \\
\hline \multicolumn{8}{|l|}{ Fat (g) } \\
\hline at 1 month & $0.564(0.475-0.652)$ & $<21.5$ & $0.49(0.38-0.61)$ & $0.58(0.48-0.67)$ & $0.54(0.47-0.62)$ & $0.58(0.4-0.83)$ & $1.45(1.09-1.92)$ \\
\hline at 6 months & $0.682(0.599-0.766)$ & $<46.5$ & $0.85(0.78-0.91)$ & $0.48(0.35-0.61)$ & $0.73(0.66-0.79)$ & $1.65(1.28-2.12)$ & $0.31(0.19-0.50)$ \\
\hline at 12 months & $0.781(0.709-0.853)$ & $<52.5$ & $0.78(0.70-0.85)$ & $0.69(0.56-0.8)$ & $0.75(0.68-0.81)$ & $2.54(1.73-3.74)$ & $0.32(0.22-0.46)$ \\
\hline \multicolumn{8}{|c|}{ Proportion of calorie at 12 months } \\
\hline Carbohydrate $(\%)$ & $0.714(0.637-0.792)$ & $<49.0$ & $0.85(0.78-0.91)$ & $0.60(0.46-0.72)$ & $0.77(0.7-0.83)$ & $2.11(1.54-2.88)$ & $0.25(0.16-0.40)$ \\
\hline Protein $(\%)$ & $0.609(0.523-0.695)$ & $>24.5$ & $0.52(0.40-0.64)$ & $0.74(0.65-0.81)$ & $0.65(0.58-0.72)$ & $1.98(1.36-2.88)$ & $0.65(0.50-0.84)$ \\
\hline Fat $(\%)$ & $0.855(0.792-0.917)$ & $<28.0$ & $0.73(0.65-0.81)$ & $0.60(0.46-0.72)$ & $0.69(0.62-0.75)$ & $1.82(1.32-2.50)$ & $0.45(0.32-0.64)$ \\
\hline
\end{tabular}

$\mathrm{CI}$, confidence interval; AUC, area under the curve; LR, likelihood ratio. * based on Youden's index. 


\section{Discussion}

Bariatric surgery is considered the best treatment for clinically severe obesity, which can result in long-term body weight loss and the control or remission of comorbidities [15]. Roux-en-Y gastric bypass (RYGB) and sleeve gastrectomy (SG) are the most common procedures used in bariatric surgery [16]. Despite its advantages, bariatric surgery may compromise nutritional status due to food intake restriction [17]. The greatest decrease in food intake occurs within the first 3 months post operation, so regular follow-ups with a clinical dietitian are important for facilitating adequate weight loss and preventing malnutrition [18,19].

Nutrition prescription is an important component of nutritional interventions for weight management. In particular, calorie prescription is the key for guiding intake amounts [20]. Over time, energy intake shows an increasing trend, with values of 1500,1700, 1800, 1900, and $2000 \mathrm{kcal} /$ day at 6 months and 1, 2, 3, and 4-10 years post operation [9]. Several studies have reported weight loss effects according to calorie restriction $[18,21]$. A very-low-calorie diet was shown to induce greater changes compared with a low-calorie diet [22]. Other studies that evaluated body nutrient composition changes following a short-term low-calorie diet of $1500 \mathrm{kcal} /$ day indicated that lean body mass accounted for $31.0-38.6 \%$ of total weight loss during the study period [23,24]. It can be quite challenging to determine the energy requirements for patients after bariatric surgery. Predictive equations are commonly used for requirement calculations, but their accuracy can vary, and they do not take into consideration body composition or usual dietary intakes, which can affect energy requirements. In this study, we found a significant difference in energy intake at 6 months after surgery, and weight loss success showed a significant correlation with energy intake. The energy intake was $835 \mathrm{kcal}$ at 1 month after surgery, and maintaining a very-low-calorie or low-calorie diet until 1 year can help with reaching the weight loss goal. However, in order to maintain a long-term weight loss, a balanced intake of nutrients should be demonstrated and there should be no nutritional deficiency, rather than simply depending on total calorie intake.

There are no precise recommendations for carbohydrate intake after surgery, but $130 \mathrm{~g}$ of carbohydrates/day provides sufficient glucose for the central nervous system [25]. Das et al. [26] suggested that a meal pattern with a high glycemic load represents an increase of $29 \%$ in energy intake compared with a meal pattern with a low glycemic load. Another study suggested that the intake of a high glycemic load is associated with a higher calorie intake and less weight loss [27]. Most studies recommended avoiding simple sugars and choosing foods rich in complex carbohydrates and dietary fiber with a low glycemic index [28]. In the present study, we could not analyze the types of starch in the diet, but carbohydrate intake showed a significant difference at 6 months postoperatively between two groups, and we instructed patients to maintain carbohydrate consumption within $173 \mathrm{~g} / \mathrm{day}$ until 1 year post operation. This cutoff value was slightly higher than the values reported in other countries. According to the 2018 Korea National Health and Nutrition Survey, the recommended carbohydrate intake for adults is $294 \mathrm{~g} /$ day, contributing $66 \%$ of total energy [29]. Rice is the staple food in Korea, and the Korean diet is based mainly on carbohydrates. Although the amount of meals increased over time during the postoperative period, carbohydrate intake was strictly restricted until 6 months in our results.

Protein intake promotes rapid postoperative recovery and helps maintain muscle mass [19]. In the American Society for Metabolic and Bariatric Surgery (ASMBS), the recommended protein requirements are 60-80 g/day or $1.5 \mathrm{~g}$ per ideal body weight to preserve body protein levels [10]. However, it is practically not easy to meet the recommended amount. Foods that are sources of protein contain fat, and so it is necessary to eat low-fat protein sources or use an oral protein supplement. The protein intake at 1 month in the success group was significantly higher compared with that in the failure group, with a protein intake exceeding $86.5 \mathrm{~g} /$ day at 12 months. However, compared with other nutrients, the cutoff value for protein intake had low accuracy in terms of predicting success after bariatric surgery. 
Finally, the results regarding the percentage of energy obtained from macronutrients were notable. Many studies have reported the following postoperative macronutrient distributions: $35-50 \%$ from carbohydrates, $15-23 \%$ from protein, and $35-42 \%$ from fat $[4,9,10]$. Swenson et al. [30] reported that subjects to either a low-fat diet or a low-carbohydrate, high-protein diet for 1 year showed significant weight loss both by a reduction in BMI and excess body weight loss. At 12 months, the recommended proportions of energy obtained from carbohydrates, protein, and fat are $<49 \%,>24.5 \%$, and $<28 \%$, respectively; the proportion of carbohydrate is especially meaningful.

This study had some limitations. Obese patients tend to underreport their dietary intakes, and therefore, the estimated energy intake may have been lower than the actual intake. Nutritional deficiencies in the subjects were not analyzed, the observation period was short, and sample size was small. It did not reflect, as a variable, whether the time and intensity of the exercise affected success. The percentage of failure group in all subjects was reported to be high at $32.8 \%$. The percentages of subjects in the total study population with $\% \mathrm{EWL}<25 \%$ were $4.2 \%$ at 1 month, $4.2 \%$ at 6 months, and $3.2 \%$ at 12 months, although these data are not presented.

A major strength of this study was that the data were detail-managed by professional dietitians. In addition, criteria for proper macronutrient intake were guided at each follow-up point after surgery, providing basic data for future nutritional guidelines. Even though the area under the curve (AUC) values did not seem to be large enough to find a good optimal cutoff point, the attempt was meaningful in establishing nutrient intake standards based on the data.

\section{Conclusions}

In conclusion, based on the data obtained at 12 months after bariatric surgery, carbohydrate and fat intake are significantly related to weight loss. Adhering to adequate nutrient intake during the postoperative period appears to be an effective treatment for morbid obesity. Further investigations are required to determine the long-term effects of bariatric surgery on weight loss, nutrient intake, and nutritional status.

Author Contributions: Conceptualization, H.-S.L.; methodology, H.-S.L. and Y.J.K.; formal analysis, H.-S.L. and B.L.; writing-original draft preparation, H.-S.L., J.L., and S.-J.Y.; writing-review and editing; H.-S.L., B.L., and Y.J.K.; supervision, Y.J.K. All authors read and approved the final manuscript.

Funding: This research received no external funding.

Conflicts of Interest: The authors declare no conflict of interest.

\section{References}

1. Yan, E.; Ko, E.; Luong, V.; Wang, H.J.; Romanova, M.; Li, Z. Long-term changes in weight loss and obesity-related comorbidities after Roux-en-Y gastric bypass: A primary care experience. Am. J. Surg. 2008, 195, 94-98. [CrossRef] [PubMed]

2. Handzlik-Orlik, G.; Holecki, M.; Orlik, B.; Wyleżoł, M.; Duława, J. Nutrition management of the post-bariatric surgery patient. Nutr. Clin. Pract. 2015, 30, 383-392. [CrossRef] [PubMed]

3. Lupoli, R.; Lembo, E.; Saldalamacchia, G.; Avola, C.K.; Angrisani, L.; Capaldo, B. Bariatric surgery and long-term nutritional issues. World J. Diabetes 2017, 8, 464-474. [CrossRef] [PubMed]

4. Sherf Dagan, S.; Goldenshluger, A.; Globus, I.; Schweiger, C.; Kessler, Y.; Kowen Sandbank, G.; Ben-Porat, T.; Sinai, T. Nutritional recommendations for adult bariatric surgery patients: Clinical practice. Adv. Nutr. 2017, 8, 382-394. [CrossRef]

5. Magro, D.O.; Geloneze, B.; Delfini, R.; Pareja, B.C.; Callejas, F.; Pareja, J.C. Long-term weight regain after gastric bypass: A 5-year prospective study. Obes. Surg. 2008, 18, 648-651. [CrossRef]

6. Hall, K.D.; Kahan, S. Maintenance of lost weight and long-term management of obesity. Med. Clin. N. Am. 2018, 102, 183-197. [CrossRef]

7. Ruiz-Lozano, T.; Vidal, J.; de Hollanda, A.; Scheer, F.; Garaulet, M.; Izquierdo-Pulido, M. Timing of food intake is associated with weight loss evolution in severe obese patients after bariatric surgery. Clin. Nutr. 2016, 35, 1308-1314. [CrossRef] 
8. Kanerva, N.; Larsson, I.; Peltonen, M.; Lindroos, A.K.; Carlsson, L.M. Changes in total energy intake and macronutrient composition after bariatric surgery predict long-term weight outcome: Findings from the Swedish Obese Subjects (SOS) study. Am. J. Clin. Nutr. 2017, 106, 136-145. [CrossRef]

9. Aills, L.; Blankenship, J.; Buffington, C.; Furtado, M.; Parrott, J. ASMBS Allied Health Nutritional Guidelines for the Surgical Weight Loss Patient. Surg. Obes. Relat. Dis. 2008, 4, S73-S108. [CrossRef]

10. Mechanick, J.I.; Apovian, C.; Brethauer, S.; Garvey, W.T.; Joffe, A.M.; Kim, J.; Kushner, R.F.; Lindquist, R.; Pessah-Pollack, R.; Seger, J.; et al. Clinical practice guidelines for the perioperative nutrition, metabolic, and nonsurgical support of patients undergoing bariatric procedures-2019 update: Cosponsored by American Association of Clinical Endocrinologists/American College of Endocrinology, The Obesity Society, American Society for Metabolic \& Bariatric Surgery, Obesity Medicine Association, and American Society of Anesthesiologists. Surg. Obes. Relat. Dis. 2020, 16, 175-247.

11. Korean Society for Metabolic and Bariatric Surgery. 2018 Korean society for metabolic and bariatric surgery guidelines. J. Metab. Bariatr. Surg. 2018, 7, 1-21. [CrossRef]

12. Kasama, K.; Mui, W.; Lee, W.J.; Lakdawala, M.; Naitoh, T.; Seki, Y.; Sasaki, A.; Wakabayashi, G.; Sasaki, I.; Kawamura, I.; et al. IFSO-APC consensus statements 2011. Obes. Surg. 2012, 22, 677-684. [CrossRef] [PubMed]

13. Snehalatha, C.; Viswanathan, V.; Ramachandran, A. Cutoff values for normal anthropometric variables in asian Indian adults. Diabetes Care 2003, 26, 1380-1384. [CrossRef]

14. Simel, D.L.; Samsa, G.P.; Matchar, D.B. Likelihood ratios with confidence: Sample size estimation for diagnostic test studies. J. Clin. Epidemiol. 1991, 44, 763-770. [CrossRef]

15. Conason, A.; Teixeira, J.; Hsu, C.H.; Puma, L.; Knafo, D.; Geliebter, A. Substance use following bariatric weight loss surgery. JAMA Surg. 2013, 148, 145-150. [CrossRef] [PubMed]

16. Madsbad, S.; Holst, J.J. Bariatric surgery-which procedure is the optimal choice? Lancet 2019, 393, $1263-1264$. [CrossRef]

17. Sandoval, D. Bariatric surgeries: Beyond restriction and malabsorption. Int. J. Obes. Lond. 2011, 35, S45-S49. [CrossRef] [PubMed]

18. McMahon, M.M.; Sarr, M.G.; Clark, M.M.; Gall, M.M.; Knoetgen, J., 3rd; Service, F.J.; Laskowski, E.R.; Hurley, D.L. Clinical management after bariatric surgery: Value of a multidisciplinary approach. Mayo Clin. Proc. 2006, 81, S34-S45. [CrossRef]

19. Schiavo, L.; Pilone, V.; Rossetti, G.; Iannelli, A. The role of the nutritionist in a multidisciplinary bariatric surgery team. Obes. Surg. 2019, 29, 1028-1030. [CrossRef]

20. Serafim, M.P.; Santo, M.A.; Gadducci, A.V.; Scabim, V.M.; Cecconello, I.; de Cleva, R. Very low-calorie diet in candidates for bariatric surgery: Change in body composition during rapid weight loss. Clin. Sao Paulo 2019, 74, e560. [CrossRef]

21. Faria, S.L.; Faria, O.P.; de Almeida Cardeal, M.; Ito, M.K. Effects of a very low calorie diet in the preoperative stage of bariatric surgery: A randomized trial. Surg. Obes. Relat. Dis. 2015, 11, 230-237. [CrossRef] [PubMed]

22. Sajoux, I.; Lorenzo, P.M.; Gomez-Arbelaez, D.; Zulet, M.A.; Abete, I.; Castro, A.I.; Baltar, J.; Portillo, M.P.; Tinahones, F.J.; Martinez, J.A.; et al. Effect of a very-low-calorie ketogenic diet on circulating myokine levels compared with the effect of bariatric surgery or a low-calorie diet in patients with obesity. Nutrients 2019, 11, 2368. [CrossRef] [PubMed]

23. Edholm, D.; Kullberg, J.; Karlsson, F.A.; Haenni, A.; Ahlström, H.; Sundbom, M. Changes in liver volume and body composition during 4 weeks of low calorie diet before laparoscopic gastric bypass. Surg. Obes. Relat. Dis. 2015, 11, 602-606. [CrossRef] [PubMed]

24. Sivakumar, J.; Chong, L.; Ward, S.; Sutherland, T.R.; Read, M.; Hii, M.W. Body composition changes following a very-low-calorie pre-operative diet in patients undergoing bariatric surgery. Obes. Surg. 2020, 30, 119-126. [CrossRef] [PubMed]

25. Snyder-Marlow, G.; Taylor, D.; Lenhard, M.J. Nutrition care for patients undergoing laparoscopic sleeve gastrectomy for weight loss. J. Am. Diet. Assoc. 2010, 110, 600-607. [CrossRef]

26. Das, S.K.; Gilhooly, C.H.; Golden, J.K.; Pittas, A.G.; Fuss, P.J.; Cheatham, R.A.; Tyler, S.; Tsay, M.; McCrory, M.A.; Lichtenstein, A.H.; et al. Long-term effects of 2 energy-restricted diets differing in glycemic load on dietary adherence, body composition, and metabolism in CALERIE: A 1-y randomized controlled trial. Am. J. Clin. Nutr. 2007, 85, 1023-1030. [CrossRef] 
27. Joslowski, G.; Halim, J.; Goletzke, J.; Gow, M.; Ho, M.; Louie, J.C.; Buyken, A.E.; Cowell, C.T.; Garnett, S.P. Dietary glycemic load, insulin load, and weight loss in obese, insulin resistant adolescents: RESIST study. Clin. Nutr. 2015, 34, 89-94. [CrossRef]

28. Nicoletti, C.F.; Cortes-Oliveira, C.; Pinhel, M.A.S.; Nonino, C.B. Bariatric surgery and precision nutrition. Nutrients 2017, 9, 974. [CrossRef]

29. Korea Centers for Disease Control and Prevention; Ministry of Health and Welfare. Korea Health Statistics 2018: Korea National Health and Nutrition Examination Survey (KNHANES VIII-3). Available online: https://knhanes.cdc.go.kr/knhanes/sub04/sub04_03.do (accessed on 10 April 2020).

30. Swenson, B.R.; Saalwachter Schulman, A.; Edwards, M.J.; Gross, M.P.; Hedrick, T.L.; Weltman, A.L.; Northrup, C.J.; Schirmer, B.D.; Sawyer, R.G. The effect of a low-carbohydrate, high-protein diet on post laparoscopic gastric bypass weight loss: A prospective randomized trial. J. Surg. Res. 2007, 142, 308-313. [CrossRef]

(c)

(C) 2020 by the authors. Licensee MDPI, Basel, Switzerland. This article is an open access article distributed under the terms and conditions of the Creative Commons Attribution (CC BY) license (http://creativecommons.org/licenses/by/4.0/). 